\title{
The Potential of Triterpenoids from Loquat Leaves (Eriobotrya japonica) for Prevention and Treatment of Skin Disorder
}

\author{
Hui Tan, Tamrakar Sonam and Kuniyoshi Shimizu * \\ Department of Agro-environmental Sciences, Faculty of Agriculture, Kyushu University, 6-10-1 Hakozaki, \\ Higashi-ku, Fukuoka 812-8581, Japan; thth229@gmail.com (H.T.); tamrakar.snm@gmail.com (T.S.) \\ * Correspondence: shimizu@agr.kyushu-u.ac.jp; Tel.: +81-092-642-3002
}

Academic Editor: Maurizio Battino

Received: 25 February 2017; Accepted: 6 May 2017; Published: 11 May 2017

\begin{abstract}
The leaves of loquat (Eriobotrya japonica) possess high medicinal value and have been used as traditional medicines. However, there are no evidence-based studies on the skin-care effects of E. japonica leaves. To explore new biological activities of E. japonica leaves against skin disorder and to gain a better understanding of the chemical components associated with bioactivities, we evaluated 18 triterpenoids from E. japonica leaves on anti-melanogenesis, anti-acne, anti-allergy and anti-aging activities. Our results revealed that eight compounds showed anti-melanogenesis activity, of which ursolic acid (1) and maslinic acid (7) were the most potent with the similar selective index to that of arbutin. Structure-activity relationship and possible mechanism of active compounds were proposed. Twelve compounds exhibited anti-acne effect; ursolic acid (1), maslinic acid (7), corosolic acid (8) and euscaphic acid (12) showed highest activities against $P$. acnes. Four compounds displayed anti-allergy and anti-inflammatory activity; 3-epicorosolic acid (9) and euscaphic acid (12) showed marked activity against $\beta$-hexosaminidase release. Finally, ursolic acid (1), pomolic acid (10), colosolic acid (8) and its methylated derivative (6) exhibited the highest anti-aging activity by stimulating collagen and hyaluronic acid (HA) production. Our findings provide valuable evidence that $E$. japonica leaves have potential applications as ingredients of function foods or cosmetics for health benefits and a number of triterpenoids may play an important role in these bioactivities.
\end{abstract}

Keywords: Eriobotrya japonica; loquat leaves; triterpenoids; skin disorder; anti-melanogenesis; anti-acne; anti-allergy; anti-aging

\section{Introduction}

The skin accounts for $15 \%$ of a human being's total body weight, and it directly confronts the external environment serving as a primary defense system [1]. It plays a crucial role in not only preventing harmful substances, such as ultraviolet radiation, microbial pathogens and antigens from entering the body, but also in the maintenance of body homeostasis. Skin generally consists of a three-layer structure: the epidermis, the dermis and subcutaneous tissues. The epidermis is the outermost layer of the skin and keratinocytes are the most abundant cell type. Keratinocytes act via their capacity to produce UV-absorbing molecules, inflammatory mediators and antimicrobial peptides [2]. The dermis is the structure beneath the epidermis, its three primary structural components are collagen, elastin and glycosaminoglycans, which have been the subjects of the majority of anti-aging research [3].

Plant-derived natural, bioactive compounds have shown potential in beauty enhancement along with health benefits against disorders, such as photo-aging, inflammation, oxidation, aging, bacterial infections and so on [4]. These bioactive compounds continue to gain popularity based on their several 
advantages, which include often having fewer side effects, showing better patient tolerance, and being relatively less expensive and acceptable due to a long history of use compared to synthetic ingredients [5]. In the search for effective drug leads from herbs used against skin abnormalities, bioactive compounds such as aloin [6], curcumin [7], resveratrol [8], gallic acid [9], quercetin, genistein and catechins [10] have been found.

Loquat (Eriobotrya japonica), a subtropical evergreen tree belonging to the Rosaceae family, is widely cultivated for its edible fruits. The leaves are well-known traditional Chinese medicine, used for the treatment of diabetic patients and for soothing effects on the digestive and respiratory systems. In Japan, loquat leaves are sold as a tasty herbal tea with health benefits. It has been reported that E. japonica leaves have great potential for the prevention of inflammation [11] and obesity [12]. In addition, loquat leaves may ameliorate Alzheimer's disease, since E. japonica leaves protect against oxidative stress and cognitive deficits induced by the $\mathrm{A} \beta$ peptide [13]. Our previous studies showed that $E$. japonica have the potential to suppress ovariectomy-induced bone mineral density deterioration [14], and isolated triterpenoids as the major bioactive compounds suppress osteoclast differentiation [15]. As a powerful indigenous therapy, loquat leaves have also been used for skin-care application such as for sunburn, dermatitis, and skin aging. However, to the best of our knowledge, no study has investigated this bioactivity and desired chemical components from loquat leaves. Pentacyclic triterpenoids are present at their highest concentration in loquat leaves, and they have been reported to be related to various bioactivities. Therefore, in the present study we evaluated the potential involvement in skin-related bioactivity of a series of triterpenoids from $E$. japonica leaves (Figure 1), including anti-melanogenesis, anti-acne, anti-allergy, and anti-aging activity.
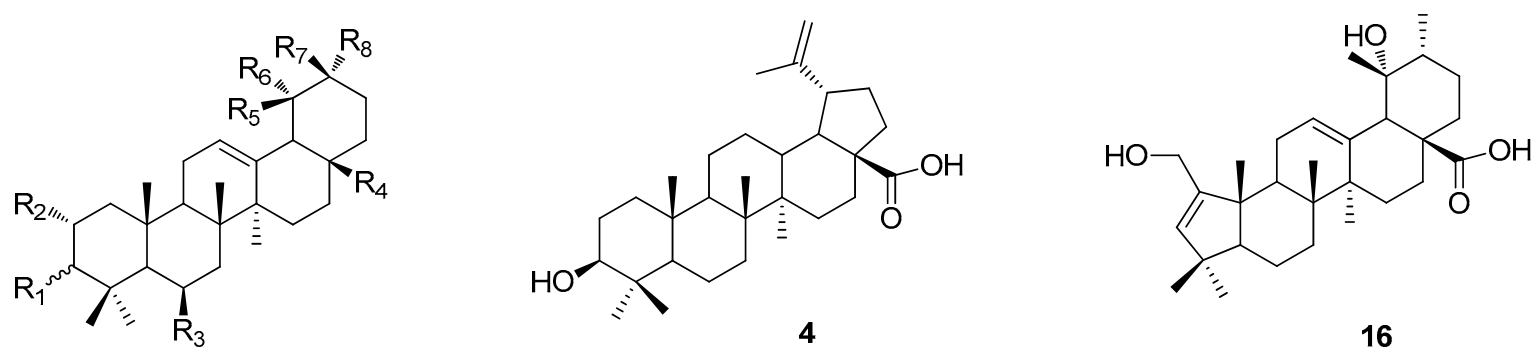

\begin{tabular}{ccccccccc}
\hline Compound & $\mathbf{R}_{\mathbf{1}}$ & $\mathbf{R}_{\mathbf{2}}$ & $\mathbf{R}_{\mathbf{3}}$ & $\mathbf{R}_{\mathbf{4}}$ & $\mathbf{R}_{\mathbf{5}}$ & $\mathbf{R}_{\mathbf{6}}$ & $\mathbf{R}_{\mathbf{7}}$ & $\mathbf{R}_{\mathbf{8}}$ \\
\hline $\mathbf{1}$ & $\beta-\mathrm{OH}$ & $\mathrm{H}$ & $\mathrm{H}$ & $\mathrm{COOH}$ & $\mathrm{Me}$ & $\mathrm{H}$ & $\mathrm{H}$ & $\mathrm{Me}$ \\
$\mathbf{2}$ & $\beta-\mathrm{OH}$ & $\mathrm{H}$ & $\mathrm{H}$ & $\mathrm{COOH}$ & $\mathrm{H}$ & $\mathrm{H}$ & $\mathrm{Me}$ & $\mathrm{Me}$ \\
$\mathbf{3}$ & $\beta-\mathrm{OH}$ & $\mathrm{H}$ & $\mathrm{H}$ & $\mathrm{CH}_{2} \mathrm{OH}$ & $\mathrm{Me}$ & $\mathrm{H}$ & $\mathrm{H}$ & $\mathrm{Me}$ \\
$\mathbf{5}$ & $\beta-\mathrm{OH}$ & $\mathrm{OH}$ & $\mathrm{H}$ & $\mathrm{COOCH}_{3}$ & $\mathrm{H}$ & $\mathrm{H}$ & $\mathrm{Me}$ & $\mathrm{Me}$ \\
$\mathbf{6}$ & $\beta-\mathrm{OH}$ & $\mathrm{OH}$ & $\mathrm{H}$ & $\mathrm{COOCH}$ & $\mathrm{Me}$ & $\mathrm{H}$ & $\mathrm{H}$ & $\mathrm{Me}$ \\
$\mathbf{7}$ & $\beta-\mathrm{OH}$ & $\mathrm{OH}$ & $\mathrm{H}$ & $\mathrm{COOH}$ & $\mathrm{H}$ & $\mathrm{H}$ & $\mathrm{Me}$ & $\mathrm{Me}$ \\
$\mathbf{8}$ & $\beta-\mathrm{OH}$ & $\mathrm{OH}$ & $\mathrm{H}$ & $\mathrm{COOH}$ & $\mathrm{Me}$ & $\mathrm{H}$ & $\mathrm{H}$ & $\mathrm{Me}$ \\
$\mathbf{9}$ & $\alpha-\mathrm{OH}$ & $\mathrm{OH}$ & $\mathrm{H}$ & $\mathrm{COOH}$ & $\mathrm{Me}$ & $\mathrm{H}$ & $\mathrm{H}$ & $\mathrm{Me}$ \\
$\mathbf{1 0}$ & $\beta-\mathrm{OH}$ & $\mathrm{H}$ & $\mathrm{H}$ & $\mathrm{COOH}$ & $\mathrm{Me}$ & $\mathrm{OH}$ & $\mathrm{H}$ & $\mathrm{Me}$ \\
$\mathbf{1 1}$ & $\beta-\mathrm{OH}$ & $\mathrm{OH}$ & $\mathrm{H}$ & $\mathrm{COOH}$ & $\mathrm{Me}$ & $\mathrm{OH}$ & $\mathrm{H}$ & $\mathrm{Me}$ \\
$\mathbf{1 2}$ & $\alpha-\mathrm{OH}$ & $\mathrm{OH}$ & $\mathrm{H}$ & $\mathrm{COOH}$ & $\mathrm{Me}$ & $\mathrm{OH}$ & $\mathrm{H}$ & $\mathrm{Me}$ \\
$\mathbf{1 3}$ & $=\mathrm{O}$ & $\mathrm{H}$ & $\mathrm{H}$ & $\mathrm{COOH}$ & $\mathrm{Me}$ & $\mathrm{H}$ & $\mathrm{H}$ & $\mathrm{Me}$ \\
$\mathbf{1 4}$ & $=\mathrm{O}$ & $\mathrm{H}$ & $\mathrm{OH}$ & $\mathrm{COOH}$ & $\mathrm{Me}$ & $\mathrm{OH}$ & $\mathrm{H}$ & $\mathrm{Me}$ \\
$\mathbf{1 5}$ & $=\mathrm{O}$ & $\mathrm{OH}$ & $\mathrm{H}$ & $\mathrm{COOH}$ & $\mathrm{Me}$ & $\mathrm{OH}$ & $\mathrm{H}$ & $\mathrm{Me}$ \\
$\mathbf{1 7}$ & $\beta-$ trans- $p$-coumaroyl & $\mathrm{OH}$ & $\mathrm{H}$ & $\mathrm{COOH}$ & $\mathrm{Me}$ & $\mathrm{OH}$ & $\mathrm{H}$ & $\mathrm{Me}$ \\
$\mathbf{1 8}$ & $\beta-$-cis- - -coumaroyl & $\mathrm{OH}$ & $\mathrm{H}$ & $\mathrm{COOH}$ & $\mathrm{Me}$ & $\mathrm{OH}$ & $\mathrm{H}$ & $\mathrm{Me}$ \\
\hline
\end{tabular}

Figure 1. The structures of the 18 tested triterpenoids from E. japonica leaves. 


\section{Results and Discussion}

\subsection{Anti-Melanogenesis Effect of Triterpenoids}

Excessive ultraviolet (UV) radiation stimulates the production of melanin, which leads to various skin injuries, including inflammation, age spots, melasma and freckles [16]. We found previously that the methanol extract of E. japonica leaves exhibited significant and dose-dependent melanogenesis inhibition in B16 melanoma cells (Figure S1). In the present study, we focused on the potential anti-melanogenesis effect of 18 triterpenoids from E. japonica leaves. We tested various concentrations' inhibitory effects on melanin synthesis and cell viability (Tables S1 and S2). The CC 50 values for cell viability and the $\mathrm{IC}_{50}$ values against the melanogenesis of B16 cells are listed in Table 1 . The relative effectiveness of the compounds for inhibiting melanogenesis compared to inducing cell death is defined as the selectivity index (S.I.). It is desirable to have a high selectivity index (S.I. > 1.0), which indicate the potential for selective melanogenesis inhibition. Our results demonstrated that eight of the compounds, namely ursolic acid (1), oleanolic acid (2), betulinic acid (4), methyl maslinate (5), methyl corosolate (6), maslinic acid (7), corosolic acid (8) and tormentic acid (11), showed melanin synthesis inhibitory activity with less cytotoxicity (S.I. > 1.0). Among them, ursolic acid (1) and maslinic acid (7) showed the highest S.I. values at 1.9, which is the same as the S.I. of arbutin, a skin-lightening ingredient commonly used in the cosmetic industry.

Table 1. Anti-melanogenesis effect of triterpenoids from E. japonica leaves.

\begin{tabular}{cccccccc}
\hline No. & $\mathbf{C C}_{\mathbf{5 0}}{ }^{\mathbf{a}}(\boldsymbol{\mu M})$ & $\mathbf{I C}_{\mathbf{5 0}}{ }^{\mathbf{b}}(\boldsymbol{\mu M})$ & $\mathbf{S . I}^{\mathbf{c}}$ & $\mathbf{N o .}$ & $\mathbf{C C}_{\mathbf{5 0}}(\boldsymbol{\mu M})$ & IC $_{\mathbf{5 0}}(\boldsymbol{\mu M})$ & S.I ${ }^{\mathbf{e}}$ \\
\hline $\mathbf{1}$ & 9.4 & 4.8 & 1.9 & $\mathbf{1 0}$ & 10.5 & 14.0 & 0.8 \\
$\mathbf{2}$ & 39.9 & 26.8 & 1.5 & $\mathbf{1 1}$ & 23.3 & 18.5 & 1.3 \\
$\mathbf{3}$ & $>45.2$ & $>45.2$ & n.d. ${ }^{\mathrm{d}}$ & $\mathbf{1 2}$ & 25.6 & 34.0 & 0.7 \\
$\mathbf{4}$ & 16.7 & 11.8 & 1.4 & $\mathbf{1 3}$ & 8.9 & 18.0 & 0.5 \\
$\mathbf{5}$ & 17.5 & 12.8 & 1.4 & $\mathbf{1 4}$ & 10.9 & 14.8 & 0.7 \\
$\mathbf{6}$ & 18.7 & 16.1 & 1.2 & $\mathbf{1 5}$ & $>42.3$ & $>42.3$ & n.d. \\
$\mathbf{7}$ & 29.3 & 18.5 & 1.9 & $\mathbf{1 6}$ & 16.5 & 21.6 & 0.8 \\
$\mathbf{8}$ & 25.8 & 18.7 & 1.4 & $\mathbf{1 7}$ & 24.0 & $>30.9$ & n.d. \\
$\mathbf{9}$ & $>42.3$ & $>42.3$ & n.d. & $\mathbf{1 8}$ & 19.5 & $>30.9$ & n.d. \\
\hline
\end{tabular}

a The $\mathrm{CC}_{50}$ value is defined as the cytotoxic concentration causing death in $50 \%$ of viable cells, and is calculated from the corresponding dose-response curves (for the individual concentrations see Table S1); ${ }^{b}$ The IC $_{50}$ value is defined as the concentration required for $50 \%$ inhibition of melanin synthesis, and is calculated from the corresponding dose-response curves (for the individual concentrations see Table S2); ${ }^{c}$ The selectivity index (S.I.) was calculated as the ratio of the concentration of the compound that is required to reduce the cell viability to $50 \%$ to the concentration of the compound needed to inhibit melanogenesis to $50 \%$ of the control value (i.e., the CC50 value/IC50 value);

d n.d.: non-detectable; ${ }^{\text {e }}$ Arbutin was used as a positive control, its S.I was calculated as 1.9.

In addition, in our comparison of the bioactive chemical structures with those of inactive compounds, we found that the beta-form of the hydroxyl group at the $R_{1}$ position may play an important role in the melanin synthesis inhibition activity, because there was a loss in this activity when the beta-form of the hydroxyl group was replaced by an alpha-form, (9) and (12), a ketone, (13)-(15), or another substituent group, (17) and (18). In addition, the carbonyl group at $R_{4}$ position may partly contribute to the activity because uvaol (3), via the presence of a hydroxymethyl group at $\mathrm{R}_{4}$, loses its activity. The methyl esterification of the carboxyl group causes a slight loss of activity, since (5) and (6) showed weaker activity than (7) and (8).

Tyrosinase is the rate-limiting enzyme for controlling the production of melanin, it can catalyze the hydroxylation of tyrosine to 3,4-dihydroxyphenylalanine (DOPA) and the oxidation of DOPA to dopaquinone [17]. From dopaquinone, the melanin synthesis pathways diverge to produce either black-to-brown eumelanin or red-to-yellow pheomelanin. In the present study, we also evaluated a potential mechanism of the active compounds against melanin synthesis by performing a tyrosinase inhibitory assay. We use either L-tyrosine or L-DOPA as the substrates. The results revealed that compounds (1), (2), (4) and (7) showed moderate inhibitory activity on tyrosinase with L-tyrosine 
as substrate at relatively high concentrations, but no inhibitory effect in the case with L-DOPA as substrate (Figure 2). This result suggests that observed melanogenesis inhibition effect among eight active compounds, compounds (1), (2), (4) and (7) are at least partly contributed by tyrosinase inhibitory activity. Our study offers preliminary evidence for selecting potential candidates that may be used as skin-whitening agents and for further clearly exploring the mechanism of each compound, melanogenesis-related enzymes including melanocortin type 1 receptor (MC1R), tyrosinase-related proteins 1 and 2 (TRP1 and TRP2), and protein kinase regulators of melanogenesis-related signaling pathways (MAPK, PKA signaling pathways) need to be further discussed.

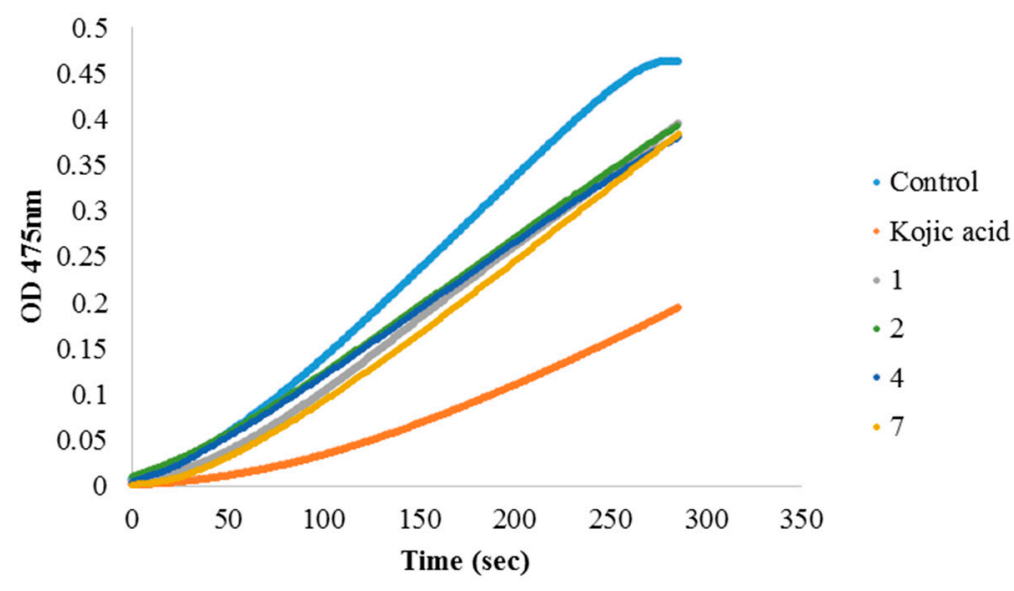

Figure 2. The effect of active compounds on tyrosinase activity (with respect to L-tyrosine). The inhibition curve of each compound was calculated under their maximum solubility of $330 \mu \mathrm{g} / \mathrm{mL}$. Kojic acid is positive control.

\subsection{Anti-Bacterial Activity of Triterpenoids}

Propionibacterium acnes (P. acnes) is an anaerobic gram-positive bacterium located primarily in the pilosebaceous unit of the skin. Together with the sebaceous gland, it plays an important role in the development of acne [18]. In our study, the antibacterial activity of triterpenoids against P. acnes was evaluated. Among these triterpenoids, 12 compounds, i.e., ursolic acid (1), oleanolic acid (2), methyl corosolate (6), maslinic acid (7), corosolic acid (8), pomolic acid (10), tormentic acid (11), euscaphic acid (12), 6ß,19-dihydroxyurs-12-en-3-oxo-28-oic acid (14), hyptadienic acid (16), 3-O-trans-p-coumaroyltormentic acid (17) and 3-O-cis-p-coumaroyltormentic acid (18), were active against $P$. acnes at their maximum solubility. The minimum inhibitory concentration (MIC) and minimum bactericidal concentration (MBC) values of the active compounds are shown in Table 2 . The results showed that ursolic acid (1), maslinic acid (7), corosolic acid (8) and euscaphic acid (12) showed the highest activities against $P$. acnes with an MIC value of $50 \mu \mathrm{g} / \mathrm{mL}$ and $\mathrm{MBC}$ values ranging from 50 to $150 \mu \mathrm{g} / \mathrm{mL}$.

Although the triterpenoids showed low hydrophilicity with $\log \mathrm{P}$ values ranging from 5 to 8 , they also exhibited high levels of antibacterial activity in the present study. However, the exact mode of action of these triterpenes on bacteria, especially against $P$. acnes, is still unknown. Antibiotic therapy (such as that with tetracyclines, erythromycin and clindamycin) directed against $P$. acnes has been a mainstay of acne treatment for many years [19], but the drug resistance associated with these antibiotics is an increasing concern [20]. Our present findings may contribute to the development of new natural cosmetic products that can be used to prevent acne, and offer an alternative plant-derived antibacterial compounds against the growth of $P$. acnes. 
Table 2. Anti-acne effect of triterpenoids from E. japonica leaves.

\begin{tabular}{|c|c|c|c|c|c|c|c|}
\hline No. & $\begin{array}{c}\text { Concentration } \\
\mu \mathrm{g} / \mathrm{mL}\end{array}$ & $\begin{array}{l}\text { Inhibition } \\
\text { Rate \% }\end{array}$ & $\begin{array}{c}\mathrm{MIC}^{\mathrm{a} / \mathrm{MBC}^{\mathrm{b}}} \\
\mu \mathrm{g} / \mathrm{mL}\end{array}$ & No. & $\begin{array}{c}\text { Concentration } \\
\mu \mathrm{g} / \mathrm{mL}\end{array}$ & $\begin{array}{c}\text { Inhibition } \\
\text { Rate } \%\end{array}$ & $\begin{array}{c}\mathrm{MIC} / \mathrm{MBC} \\
\mu \mathrm{g} / \mathrm{mL}\end{array}$ \\
\hline 1 & 100 & $109.8 \pm 0.5$ & $50 / 100$ & 10 & 100 & $84.4 \pm 1.2$ & n.d. \\
\hline 2 & 100 & $100.4 \pm 0.8$ & $100 / 200$ & 11 & 100 & $102.8 \pm 2.1$ & $100 / 200$ \\
\hline 3 & 50 & $-{ }^{c}$ & - & 12 & 100 & $98.5 \pm 1.3$ & $50 / 50$ \\
\hline 4 & 100 & - & - & 13 & 100 & - & - \\
\hline 5 & 100 & - & - & 14 & 100 & $87.6 \pm 7.4$ & n.d. \\
\hline 6 & 100 & $77.9 \pm 1.6$ & n.d. ${ }^{d}$ & 15 & 100 & - & - \\
\hline 7 & 100 & $104.1 \pm 3.1$ & $50 / 150$ & 16 & 100 & $103.9 \pm 3.1$ & $100 / 200$ \\
\hline 8 & 100 & $105.9 \pm 0.4$ & $50 / 100$ & 17 & 100 & $101.4 \pm 2.1$ & $100 / 200$ \\
\hline 9 & 100 & - & - & 18 & 100 & $103.5 \pm 2.2$ & $100 / 200$ \\
\hline
\end{tabular}

a The minimum inhibitory concentration (MIC) is the lowest concentration of an anti-bacterial agent required to completely inhibit the growth of a particular bacterium; ${ }^{b}$ The minimum bactericidal concentration (MBC) is the lowest concentration of an antibacterial agent required to kill the bacterium; ${ }^{-}{ }^{c}$ : no inhibition; n.d. ${ }^{d}$ : non-detectable; ${ }^{\mathrm{e}}$ Benzalkonium chloride was used as the positive control and showed $100 \%$ inhibition of bacterial growth at the conc. of $200 \mu \mathrm{g} / \mathrm{mL}$.

\subsection{Anti-Allergic and Anti-Inflammatory Effects of Triterpenoids}

Allergy and inflammation can manifest as hyper-responsiveness to allergenic environmental substances in various target organs of the body (the skin, nose, lungs, gastrointestinal tract, etc.) [21]. In the case of skin as the primary interface between the body and the environment, inappropriate or misdirected immune activity results in inflammations such as skin rash, itching or eczema [22]. Allergic reactions are triggered when allergens cross-link preformed immunoglobulin $\mathrm{E}$ (IgE) bound to the high-affinity receptor (FcERI) on mast cells [23]. The mast cells then degranulate and release vasoactive amines (mainly histamine), mediators (nitric oxide, prostaglandins and cysteinyl leukotrienes), chemokines and other cytokines [24].

Here we examined the anti-allergic effects by checking the release of $\beta$-hexosaminidase from IgE-stimulated RBL-2H3 mast cells. First, we selected several working concentrations for all tested compounds and the result demonstrated that four triterpenoids exhibited significant inhibitory activity at $25 \mu \mathrm{g} / \mathrm{mL}(p<0.01 ; 25 \mu \mathrm{g} / \mathrm{mL}$ is maximum solubility) as shown in Table S3. Three triterpenoids in particular-ursolic acid (1, inhibitory rate 72.5\%), 3-epicorosolic acid (9, inhibitory rate $54.4 \%)$ and euscaphic acid (12, inhibitory rate $74.5 \%$ )-significantly suppressed the release of $\beta$-hexosaminidase at a non-cytotoxic concentration. Maslinic acid (7) showed a suppression rate of $66 \%$ on $\beta$-hexosaminidase with $84.4 \%$ cell viability.

We also determined the $\mathrm{IC}_{50}$ values against the anti-allergy and anti-inflammatory activity of active compounds. As shown in Table 3, compounds (1), (7), (9) and (12) possessed inhibitory activity against $\beta$-hexosaminidase release with the $\mathrm{IC}_{50}$ value of $39.5,22.86,14.2$ and $15.8 \mu \mathrm{M}$, respectively.

Table 3. Anti-allergy and anti-inflammatory effects of triterpenoids from E. japonica leaves.

\begin{tabular}{|c|c|c|c|c|c|}
\hline \multirow{2}{*}{ No. } & \multirow{2}{*}{$\mathrm{IC}_{50}(\mu \mathrm{M})$} & $25 \mu \mathrm{g} / \mathrm{mL}$ & $12.5 \mu \mathrm{g} / \mathrm{mL}$ & $5 \mu \mathrm{g} / \mathrm{mL}$ & $1 \mu \mathrm{g} / \mathrm{mL}$ \\
\hline & & \multicolumn{4}{|c|}{ Inhibition Rate (\%) } \\
\hline 1 & 39.5 & $72.5 \pm 3.0^{* *}$ & $37.6 \pm 3.0 *$ & $0.0 \pm 11.5$ & n.d. \\
\hline 7 & 22.8 & $66.0 \pm 2.6^{*}$ & $58.2 \pm 3.0 *$ & $9.5 \pm 6.6$ & n.d. \\
\hline 9 & 14.2 & $54.4 \pm 4.9 *$ & $50.7 \pm 3.2$ * & $33.7 \pm 6.9$ & $8.9 \pm 5.2$ \\
\hline 12 & 15.8 & $74.5 \pm 1.3^{* *}$ & $67.0 \pm 1.8^{* *}$ & $37.7 \pm 3.9 *$ & $10.4 \pm 10.8$ \\
\hline
\end{tabular}

Quercetin was used as the positive control and showed the inhibition rate of $\beta$-hexosaminidase release of $72.5 \pm 3.0 \%$ without cytotoxicity at $82 \mu$ M. n.d.: non-detectable. ${ }^{*} p<0.05$ and ${ }^{* *} p<0.01$.

Our results are consistent with previous studies [25,26] showing that compounds (1), (7), (9) and (12) have significant inhibitory activity against inflammation induced by 12-O-tetradecanoylphorbol-13-acetate (TPA) in mice and TPA-induced Epstein-Barr virus early antigen 
activation. In the present study, we reveal a probable alternative mechanism to account for the anti-allergy and anti-inflammatory activity of the active compounds.

\subsection{Skin Type I Collagen Production-Promoting Activity of Triterpenoids}

Skin aging is characterized by atrophy of the dermal-epidermal junction with a decrease in mechanical tension and loss of elasticity, due mainly to marked reduction of the dermal extracellular matrix, including collagen, elastin, and hyaluronic acid [27,28]. Collagen secreted by normal human dermal fibroblasts (NHDFs) plays important roles in cell-cell adhesion, cell proliferation and cell differentiation, and thus the functional properties of the skin depends on the quality and condition of the collagen present in the dermis [29].

In our method, both the collagen production activity $(\mathrm{CP})$ and cell viability $(\mathrm{CV})$ were calculated individually at several concentrations for each compound. We then determined the $\mathrm{CP} / \mathrm{CV}$ ratio (value $>1.0$ ), which represents the "ratio of the mean of collagen production (\%) to the mean of cell viability (\%)" as an index of the stimulating activity of collagen production per cell. As shown in Figure 3, our results demonstrated that some triterpenoids can significantly enhance the dermal fibroblast collagen production per cell. Of the 18 test triterpenoids, ten induced type I collagen production at a concentration of $10 \mu \mathrm{g} / \mathrm{mL}$, with methyl corosolate (6) and corosolic acid (8) showing especially potent stimulation of up to 3.4- and 3.6-fold that of the control, and the rest of the compounds showed a moderate promoting effect. At $5 \mu \mathrm{g} / \mathrm{mL}, 16$ compounds triggered increased collagen production, with ursolic acid (1) and betulinic acid (4) increasing the collagen production up to 3.8- and 3.0-fold over the control level, respectively. Six compounds showed collagen-promoting activity at low concentrations. Concentrations higher than $10 \mu \mathrm{g} / \mathrm{mL}$ are not shown because of cytotoxicity.

\begin{tabular}{cccc}
\hline \multicolumn{4}{c}{ CP/ CV value* } \\
\hline & $10 \mu \mathrm{g} / \mathrm{mL}$ & $5 \mu \mathrm{g} / \mathrm{mL}$ & $1 \mu \mathrm{g} / \mathrm{mL}$ \\
\hline $\mathbf{1}$ & 2.0 & 3.8 & - \\
$\mathbf{2}$ & 1.1 & - & - \\
$\mathbf{3}$ & 2.6 & 2.0 & - \\
$\mathbf{4}$ & 2.6 & 3.0 & 1.6 \\
$\mathbf{5}$ & - & 1.2 & - \\
$\mathbf{6}$ & 3.6 & 2.4 & - \\
$\mathbf{7}$ & 2.7 & 1.9 & - \\
$\mathbf{8}$ & 3.4 & 2.5 & 1.2 \\
$\mathbf{9}$ & - & 1.3 & 1.2 \\
$\mathbf{1 0}$ & 2.8 & 1.2 & 1.1 \\
$\mathbf{1 1}$ & - & 1.3 & - \\
$\mathbf{1 2}$ & - & 1.5 & - \\
$\mathbf{1 3}$ & 1.4 & 1.2 & 1.2 \\
$\mathbf{1 4}$ & 1.1 & 1.4 & 1.2 \\
$\mathbf{1 5}$ & - & 1.1 & - \\
$\mathbf{1 6}$ & - & - & - \\
$\mathbf{1 7}$ & - & 1.2 & - \\
$\mathbf{1 8}$ & - & 1.1 & - \\
\hline & & &
\end{tabular}

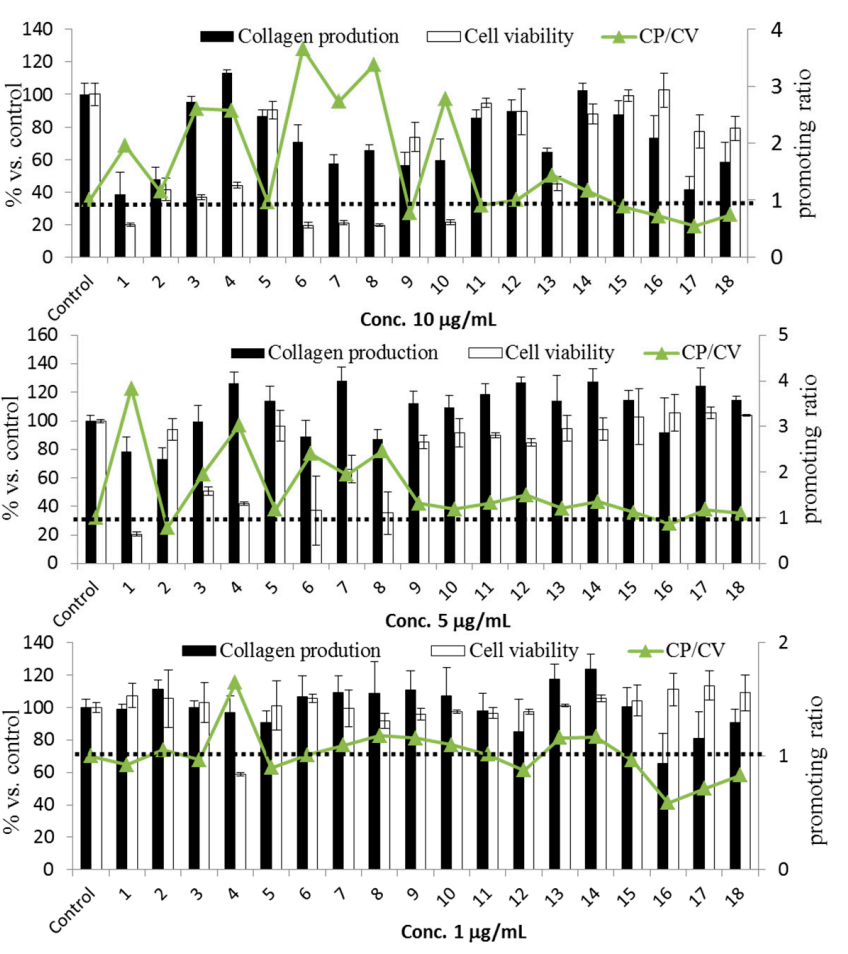

Figure 3. Collagen production (CP) - promoting effects of triterpenoids from leaves of E. japonica leaves. Data are the means $\pm \mathrm{SD}$ of three independent tests, and all data were calculated as the percentage compared with the control value. Ascorbic acid $(100 \mu \mathrm{M})$ was used as a positive control. * The promoting ratio (or $\mathrm{CP} / \mathrm{CV}$ value) represents the mean of collagen production $(\%) /$ the mean of cell viability (CV) (\%). 
Our results may contribute to the development of new cosmeceuticals and formulas from natural resources that can facilitate both the repair of skin wrinkles and fight against skin aging [30].

\subsection{Stimulating Effect of Triterpenoids on Hyaluronic Acid Synthesis}

The loss of the skin's high water content is one of the hallmarks of skin aging. The key molecule involved in skin moisture is hyaluronic acid, which is a high molecular weight glycosaminoglycan with a unique capacity to retain water [31]. Increasing amount of hyaluronic acid is also important for the wound healing process [32].

We therefore evaluated the potential effect of triterpenoids on hyaluronic acid production (Figure 4). At $10 \mu \mathrm{g} / \mathrm{mL}$, ten compounds exhibited a potent stimulatory effect on hyaluronic acid production in human dermal fibroblasts, with the compounds corosolic acid (8) and pomolic acid (10) showing the strongest hyaluronic acid stimulating activity of 5.9- and 5.8-fold that of the control, respectively; methylation derivative (6) also showed a high stimulating effect. At $5 \mu \mathrm{g} / \mathrm{mL}$, six compounds stimulated hyaluronic acid production, and it is worth noting that ursolic acid (1) achieved a 4.7 -fold increase in hyaluronic acid (HA) production. At a low concentration $(1 \mu \mathrm{g} / \mathrm{mL})$, however, only betulinic acid (4) had a promoting effect. Concentrations higher than $10 \mu \mathrm{g} / \mathrm{mL}$ are not shown because of cytotoxicity.

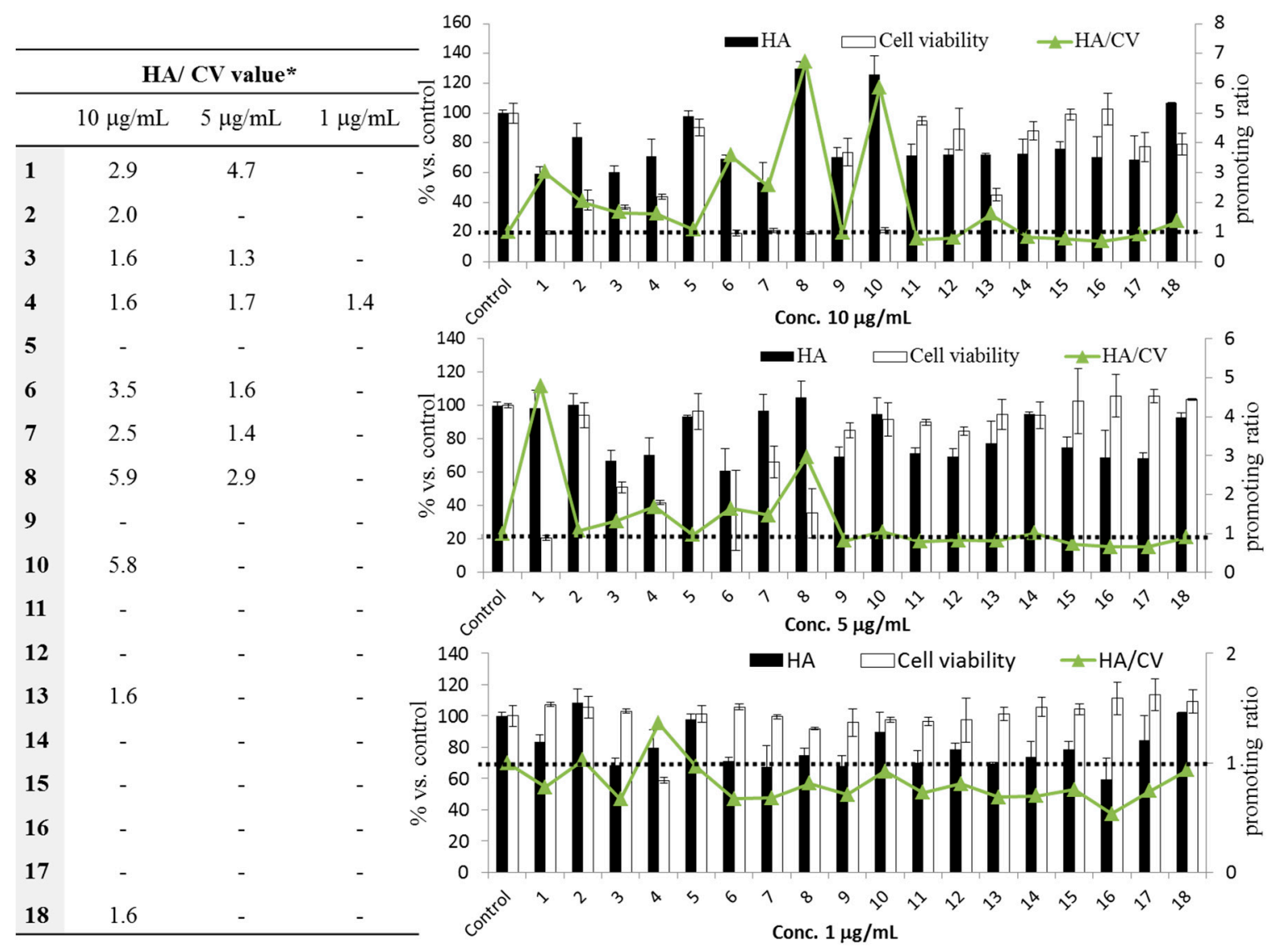

Figure 4. Stimulatory effects of triterpenoids from E. japonica leaves on hyaluronic acid (HA) production. Data are the means \pm SD of three independent tests, and all data were calculated as percentages compared with the control values. Ascorbic acid $(100 \mu \mathrm{M})$ was used as a positive control. * The promoting ratio (or HA/CV value) represents the mean of hyaluronic acid (\%)/the mean of cell viability (\%). 
Our present findings did not reveal a direct reason for the accumulation of collagen and hyaluronic acid by triterpenoids, but a pair of studies have shown that triterpenes extracted from the medicinal herb Centella asiatica induced changes in hyaladherin TNF alpha induced protein 6 (TNFAIP6) and cytokine expression, and both of these changes were expected to lower the rate of proteolysis in the extracellular matrix and support accumulation collagen, the triterpenes did not directly affect the expression levels of collagen gene [33,34]. It seems that the stimulation of hyaluronic acid synthesis by triterpenoids could also account for the inhibitory effect on hyaluronidase, an enzyme that degrades hyaluronic acid by cleaving the $N$-acetylglucosamidic bonds of hyaluronic acid via a $\beta$-elimination process to produce hyaluronic acid oligosaccharides [35].

\section{Materials and Methods}

\subsection{Chemicals}

Triterpenoids isolated from E. japonica leaves for biological activities were obtained as follow: Ursolic acid (1) was obtained from Wako Pure Chemical Industries (Osaka, Japan); Oleanolic acid (2) was from Cayman Chemicals (Ann Arbor, MI, USA); Uvaol (3) was obtained from Extrasynthese (Genay Cedex, France); Betulinic acid (4) was obtained from Focus Biomolecules (Plymouth Meeting, PA, USA); Maslinic acid (7) was obtained from Cayman Chemicals; Pomolic acid (10) was obtained from Quality Phytochemicals (East Brunswick, NJ, USA); Corosolic acid (8), 3-epicorosolic acid (9), tormentic acid (11), euscaphic acid (12), 3-oxours-12-en-28-oic acid (13), 6ß,19-dihydroxyurs-12-en-3-oxo-28-oic acid (14), hyptadienic acid (16), 3-O-trans- $p$-coumaroyl tormentic acid (17) and 3-O-cis-p-coumaroyl tormentic acid (18) were obtained from Chemfaces (Wuhan, China). Methyl maslinate (5), methyl corosolate (6) and $2 \alpha, 19 \alpha$-dihydroxy-3-oxo-12-ursen-28-oic acid (15) were previously isolated from E. japonica leaves. The purity of all tested compounds was above $95 \%$ as verified by analytical high-performance liquid chromatography (HPLC).

\subsection{Anti-Melanogenesis Assay}

This assay was performed as described by Arung et al. [17]. The mouse melanoma cell line B16 was obtained from the Riken Bioresource Center Cell Bank (Tsukuba, Japan). The B16 melanoma cells were maintained in Eagle's Minimal Essential Medium (EMEM, Nissui Chemical, Tokyo) supplemented with $10 \%(v / v)$ fetal bovine serum (FBS; Gibco, Carlsbad, CA, USA) and $0.09 \mathrm{mg} / \mathrm{mL}$ theophylline (Sigma-Aldrich, St. Louis, MO, USA). The cells were placed in 24-well plastic culture plates at a density of $1 \times 10^{5}$ cells/well and incubated for $24 \mathrm{~h}$ in media prior to being treated with the samples. After 24 $\mathrm{h}$, test samples were dissolved in DMSO $(<0.2 \%$ per well $)$ and sample solution were added to each well. Arbutin (Tokyo Kasei Kogyo, Tokyo) was used as a positive control. The cells were incubated for an additional $48 \mathrm{~h}$, and then the medium was replaced with fresh medium containing each sample again. After $24 \mathrm{~h}$, the melanin content and the cell viability were measured using a microplate reader (BioTek-ELX800, BioTek Instruments, Winooski, VT, USA) at $405 \mathrm{~nm}$ and $570 \mathrm{~nm}$, respectively. Cell viability was measured using the MTT (3-(4,5-dimethylthiazol-2-yl)-2,5-diphenyltetrazolium bromide) method.

\subsection{Tyrosinase Inhibition Assay Assay}

Tyrosinase inhibition activity was evaluated by using L-tyrosine and L-DOPA as substrates, as described [36]. Briefly, $333 \mu \mathrm{L}$ of $2.5 \mathrm{mM}$ L-tyrosine or L-DOPA solution (Sigma-Aldrich) was mixed with $600 \mu \mathrm{L}$ of $0.1 \mathrm{M}$ phosphate buffer ( $\mathrm{pH}$ 6.8) and incubated at $25^{\circ} \mathrm{C}$. Then, $33 \mu \mathrm{L}$ of the sample solution (dissolved in DMSO in various concentrations) and $33 \mu \mathrm{L}$ of 1380 units/mL mushroom tyrosinase (Sigma-Aldrich) were added to the mixture. The optical density was measured at $475 \mathrm{~nm}$ up to the appropriate time. Kojic acid (Sigma-Aldrich) was used as the positive control; the final concentration is $3.3 \mu \mathrm{g} / \mathrm{mL}$. 


\subsection{Anti-Bacterial Assay}

The antibacterial assay was based mostly on the methods described by Tanaka et al. with slight modification [37]. Propionibacterium acne (NBRC 107605) was used for the antibacterial assay. A single colony of the test strain was taken and $5 \mathrm{~mL}$ of Gifu anaerobic medium (GAM) broth (Nissui, Tokyo) was added to it. This culture was incubated at $37{ }^{\circ} \mathrm{C}$ for $30 \mathrm{~h}$. It was then added to the bacterial suspension to prepare a bacterial concentration at $10^{5} \mathrm{CFU} / \mathrm{mL}$. The bacterial solution was used for the subsequent antibacterial assay. Each compound was dissolved in DMSO, and benzalkonium chloride (Wako) was used as a positive control. The plate was incubated at $37^{\circ} \mathrm{C}$ for $30 \mathrm{~h}$. Finally, bacterial growth was measured by a microplate reader at $630 \mathrm{~nm}$. The MIC and MBC were evaluated by the standard broth microdilution method.

\subsection{Anti-Allergic and Anti-Inflammatory Assay}

The anti-allergy assay was based mostly on the methods described by Zhu et al. [38] and Yun et al. with slight modification [39]. Rat basophilic leukemia (RBL-2H3) cells were obtained from the Riken Bio-resource Center Cell Bank (Tsukuba, Japan). RBL-2H3 cells were incubated in EMEM medium containing $10 \% \mathrm{FBS}$ and $1 \%$ antibiotics-antimycotics at $37{ }^{\circ} \mathrm{C}$. The cells were seeded on a 96-well plate $\left(2 \times 10^{5}\right.$ cells /well). After $24 \mathrm{~h}$ of incubation, the medium was supplemented with $0.5 \mu \mathrm{g} / \mathrm{mL}$ anti-DNP (dinitrophenol) mouse immunoglobulin E (IgE) (Sigma-Aldrich). After an additional $24 \mathrm{~h}$ of incubation, the medium was replaced with $100 \mu \mathrm{L}$ of Tyrode buffer. The sample dissolved in DMSO $(<0.5 \%$ per well) was added, and the cell plate was incubated again for $30 \mathrm{~min}$, then replaced with $100 \mu \mathrm{L}$ of tyrode buffer containing $50 \mu \mathrm{g} / \mathrm{mL}$ DNP-bovine serum albumin (BSA) (Invitrogen, Carlsbad, CA, USA). After $1 \mathrm{~h}$ of incubation, $50 \mu \mathrm{L}$ of the supernatant was collected from each well and mixed with $50 \mu \mathrm{L}$ of substrate solution ( $p$-nitrophenyl- $N$-acetyl- $\beta$-glucosaminide, $2 \mathrm{mM}$; Sigma-Aldrich) in a new 96-well plate. The mixture was incubated at room temperature on a shaker for $3 \mathrm{~h}$. Finally, $100 \mu \mathrm{L}$ of stop solution was added, and the absorbance was read at $405 \mathrm{~nm}$. A parallel MTT experiment was performed to measure the cell viability. The MTT experiment was done exactly as described [40].

\subsection{Skin Collagen Synthesis Promoting Assay}

The assay for measuring the promotion of skin collagen synthesis was described by Kishikawa et al. [41]. Adult NHDF cells (Lonza, Tokyo) were routinely maintained in 10\% FBS and $1 \%$ antibiotic-antimycotic (Invitrogen) in Dulbecco's modified Eagle's medium (DMEM, Wako). After growing to confluence, cells at a density of $5 \times 10^{3}$ cells/well were seeded on 96-well plates for $24 \mathrm{~h}$ before the treatment. The medium was replaced with a mixture of $1 \mu \mathrm{L}$ of sample solution (DMSO $<0.5 \%$ per well) and $99 \mu \mathrm{L}$ of DMEM supplemented with $0.5 \%$ FBS. After $72 \mathrm{~h}$ of cultivation, the amount of collagen in the medium was measured using a human type I collagen enzyme-linked immunosorbent assay (ELISA) kit (ACEL, Kanagawa, Japan). The amount of collagen production was calculated using a standard curve prepared by measurement by the same ELISA. The cells remaining in the 96-well plate were subjected to an MTT assay. Ascorbic acid (100 $\mu \mathrm{M}$, Wako) was used as a positive control.

\subsection{Hyaluronic Acid Production Assay}

NHDF-Ad cells were seeded on 96-well plates $\left(5 \times 10^{3}\right.$ cells $/$ well $)$ for $24 \mathrm{~h}$ before the treatment. The medium was replaced with a mixture of $1 \mu \mathrm{L}$ of sample solution (DMSO $<0.5 \%$ per well) and $99 \mu \mathrm{L}$ of DMEM supplemented with $0.5 \%$ FBS. After $72 \mathrm{~h}$ cultivation, the amount of hyaluronic acid in the medium was measured using a QnE Hyaluronic acid ELISA kit (Biotech Trading Partners, Encinitas, CA, USA). The amount of hyaluronic acid production was quantitatively calculated from the standard curve. Cell viability was measured by the MTT method, and ascorbic acid was used as a positive control. 


\subsection{Statistical Analysis}

All values from three independently repeated experiments are presented as the mean \pm standard deviation. The significance of differences between means for two groups was determined by Student's $t$-test. Differences were considered significant at ${ }^{*} p<0.05$ and ${ }^{* *} p<0.01$. The $\mathrm{IC}_{50}$ and $\mathrm{CC}_{50}$ values were calculated from the corresponding dose-response curves in at least four concentrations.

\section{Conclusions}

By establishing a complete skin-related bioactivity evaluation method and using previous studied secondary metabolites from the leaves of E. japonica, we have obtained a better understanding of the multiple functions of E. japonica leaves, and provided an evidence-based study that E. japonica leaves can be used to prevent skin-related problems. It is clear that triterpenoids from E. japonica leaves exhibit powerful skin-protecting effects, such as the inhibition of melanogenesis, $P$. acnes growth and allergies, and the promotion effects for collagen/hyaluronic acid production. In contrast to the previously identified anti-melanogenesis, anti-acne, anti-allergy, and anti-aging triterpenoids, newly identified and more potent inhibitors were identified in our study.

In terms of anti-melanogenesis activity, we identified eight compounds that have melanin synthesis inhibitory activity. By means of a structure-activity relationship study, we deduced the functional groups that contribute to activity. The mechanism underlying four active compounds' melanogenesis inhibition effect is partly associated with their tyrosinase-inhibitory activities. There has been very little reported research about $P$. acne growth inhibition by triterpenoids, and here we found twelve compounds that were active against $P$. acnes at their maximum solubility. These compounds could be considered an alternative source to combat antibiotics resistance. However, the mechanism of action of each active component remains unknown and further research of this chemical class is needed. With regards to anti-allergy activity, our present findings revealed an alternative mechanism of active triterpenoids from $E$. japonica leaves by suppressing $\beta$-hexosaminidase. In addition, treatment using triterpenoids from the leaves of E. japonica can efficiently restore collagen and hyaluronic acid synthesis, as we observed a 3- to 4-fold increase in the level of collagen content and a 5- to 6-fold increase in hyaluronic acid synthesis.

Triterpenes represent a promising class of multi-target agents. In this study, the compounds ursolic acid (1) and maslinic acid (7) showed multiple activities against different skin-related problems. The mechanism underlying their multi-targets is interesting. The synergistic effects of these triterpenoids should also be considered. The results of this study indicate that $E$. japonica leaves have great potential to be used as ingredients in function food for increasing nutritional value and in cosmetics for skin-care effect.

Supplementary Materials: Supplementary materials can be found at www.mdpi.com/1422-0067/18/5/1030/s1. Acknowledgments: We thank the technical assistance from Scarpa Co., Ltd. (Nagasaki, Japan).

Author Contributions: Hui Tan and Kuniyoshi Shimizu conceived, designed the experiments; Hui Tan performed the experiment, analyzed the data and wrote the paper; Tamrakar Sonam helped revise the paper and did additional experiments during revision; Kuniyoshi Shimizu supervised the experiments. All authors read and approved the final manuscript.

Conflicts of Interest: The authors declare no conflict of interest.

\section{Abbreviations}

$\begin{array}{ll}\text { CV } & \text { Cell viability } \\ \text { CP } & \text { Collagen production activity } \\ \text { HA } & \text { Hyaluronic acid } \\ \text { MIC } & \text { Minimum inhibitory concentration } \\ \text { MBC } & \text { Minimum bactericidal concentration } \\ \text { S.I. } & \text { Selectivity index }\end{array}$




\section{References}

1. Lee, S.H.; Jeong, S.K.; Ahn, S.K. An update of the defensive barrier function of skin. Yonsei Med. J. 2006, 47, 293-306. [CrossRef] [PubMed]

2. Xue, M.; Jackson, C.J. Novel functions of the anticoagulant activated protein C in maintaining skin barrier integrity to impact on skin disease. Pathobiology 2015, 82, 100-106. [CrossRef] [PubMed]

3. Ganceviciene, R.; Liakou, A.I.; Theodoridis, A.; Makrantonaki, E.; Zouboulis, C.C. Skin anti-aging strategies. Dermatoendocrinology 2012, 4, 308-319. [CrossRef] [PubMed]

4. Ganesan, P.; Choi, D.-K. Current application of phytocompound-based nanocosmeceuticals for beauty and skin therapy. Int. J. Nanomed. 2016, 11, 1987-2007. [CrossRef] [PubMed]

5. Tabassum, N.; Hamdani, M. Plants used to treat skin diseases. Pharmacogn. Rev. 2014, 8, 52-60. [CrossRef] [PubMed]

6. Liu, F.-W.; Liu, F.-C.; Wang, Y.-R.; Tsai, H.-I.; Yu, H.-P. Aloin protects skin fibroblasts from heat stress-induced oxidative stress damage by regulating the oxidative defense system. PLoS ONE 2015, 10, e0143528. [CrossRef] [PubMed]

7. Hwang, B.-M.; Noh, E.-M.; Kim, J.-S.; Kim, J.-M.; You, Y.-O.; Hwang, J.-K.; Kwon, K.-B.; Lee, Y.-R. Curcumin inhibits UVB-induced matrix metalloproteinase-1/3 expression by suppressing the MAPK-p38/JNK pathways in human dermal fibroblasts. Exp. Dermatol. 2013, 22, 371-374. [CrossRef] [PubMed]

8. Ndiaye, M.; Philippe, C.; Mukhtar, H.; Ahmad, N. The grape antioxidant resveratrol for skin disorders: Promise, prospects, and challenges. Arch. Biochem. Biophys. 2011, 508, 164-170. [CrossRef] [PubMed]

9. Su, T.-R.; Lin, J.-J.; Tsai, C.-C.; Huang, T.-K.; Yang, Z.-Y.; Wu, M.-O.; Zheng, Y.-Q.; Su, C.-C.; Wu, Y.-J. Inhibition of melanogenesis by gallic acid: Possible involvement of the PI3K/Akt, MEK/ERK and Wnt/ $\beta$-catenin signaling pathways in B16F10 cells. Int. J. Mol. Sci. 2013, 14, 20443-20458. [CrossRef] [PubMed]

10. Li, N.; Deng, L.; Xiang, L.; Liang, Y. Photoprotective effect of tea and its extracts against ultraviolet radiation-induced skin disorders. Trop. J. Pharm. Res. 2014, 13, 475. [CrossRef]

11. Cha, D.S.; Eun, J.S.; Jeon, H. Anti-inflammatory and antinociceptive properties of the leaves of Eriobotrya japonica. J. Ethnopharmacol. 2011, 134, 305-312. [CrossRef] [PubMed]

12. Shih, C.-C.; Lin, C.-H.; Wu, J.-B. Eriobotrya japonica improves hyperlipidemia and reverses insulin resistance in high-fat-fed mice. Phytother. Res. 2010, 24, 1769-1780. [CrossRef] [PubMed]

13. Kim, M.-J.; Lee, J.; Seong, A.-R.; Lee, Y.-H.; Kim, Y.-J.; Baek, H.-Y.; Kim, Y.J.; Jun, W.J.; Yoon, H.-G. Neuroprotective effects of Eriobotrya japonica against $\beta$-amyloid-induced oxidative stress and memory impairment. Food Chem. Toxicol. 2011, 49, 780-784. [CrossRef] [PubMed]

14. Tan, H.; Furuta, S.; Nagata, T.; Ohnuki, K.; Akasaka, T.; Shirouchi, B.; Sato, M.; Kondo, R.; Shimizu, K. Inhibitory effects of the leaves of loquat (Eriobotrya japonica) on bone mineral density loss in ovariectomized mice and osteoclast differentiation. J. Agric. Food Chem. 2014, 62, 836-841. [CrossRef] [PubMed]

15. Tan, H.; Ashour, A.; Katakura, Y.; Shimizu, K. A structure-activity relationship study on antiosteoclastogenesis effect of triterpenoids from the leaves of loquat (Eriobotrya japonica). Phytomedicine 2015, 22, 498-503. [CrossRef] [PubMed]

16. Choi, M.-H.; Shin, H.-J. Anti-melanogenesis effect of quercetin. Cosmetics 2016, 3, 18. [CrossRef]

17. Arung, E.T.; Furuta, S.; Ishikawa, H.; Kusuma, I.W.; Shimizu, K.; Kondo, R. Anti-melanogenesis properties of quercetin- and its derivative-rich extract from Allium cepa. Food Chem. 2011, 124, 1024-1028. [CrossRef]

18. Beylot, C.; Auffret, N.; Poli, F.; Claudel, J.-P.; Leccia, M.-T.; Del Giudice, P.; Dreno, B. Propionibacterium acnes: An update on its role in the pathogenesis of acne. J. Eur. Acad. Dermatol. Venereol. 2014, 28, 271-278. [CrossRef] [PubMed]

19. Eady, E.A.; Gloor, M.; Leyden, J.J. Propionibacterium acnes resistance: A worldwide problem. Dermatology 2003, 206, 54-56. [CrossRef] [PubMed]

20. Walsh, T.R.; Efthimiou, J.; Dréno, B. Systematic review of antibiotic resistance in acne: An increasing topical and oral threat. Lancet Infect. Dis. 2016, 16, 23-33. [CrossRef]

21. Juckmeta, T.; Thongdeeying, P.; Itharat, A.; Juckmeta, T.; Thongdeeying, P.; Itharat, A. Inhibitory effect on $\beta$-hexosaminidase release from RBL-2H3 cells of extracts and some pure constituents of benchalokawichian, a Thai herbal remedy, used for allergic disorders. Evid. Based Complement. Altern. Med. 2014, 2014, 1-8. [CrossRef] [PubMed] 
22. Kupper, T.S.; Fuhlbrigge, R.C. Immune surveillance in the skin: Mechanisms and clinical consequences. Nat. Rev. Immunol. 2004, 4, 211-222. [CrossRef] [PubMed]

23. Charles, A.J.; Travers, P.; Walport, M.; Shlomchik, M.J. Effector Mechanisms in Allergic Reactions; Garland Science: New York, NY, USA, 2001.

24. Larché, M.; Akdis, C.A.; Valenta, R. Immunological mechanisms of allergen-specific immunotherapy. Nat. Rev. Immunol. 2006, 6, 761-771. [CrossRef] [PubMed]

25. Banno, N.; Akihisa, T.; Tokuda, H.; Yasukawa, K.; Taguchi, Y.; Akazawa, H.; Ukiya, M.; Kimura, Y.; Suzuki, T.; Nishino, H. Anti-inflammatory and antitumor-promoting effects of the triterpene acids from the leaves of Eriobotrya japonica. Biol. Pharm. Bull. 2005, 28, 1995-1999. [CrossRef] [PubMed]

26. Banno, N.; Akihisa, T.; Tokuda, H.; Yasukawa, K.; Higashihara, H.; Ukiya, M.; Watanabe, K.; Kimura, Y.; Hasegawa, J.-I.; Nishino, H. Triterpene acids from the leaves of Perilla frutescens and their anti-inflammatory and antitumor-promoting effects. Biosci. Biotechnol. Biochem. 2004, 68, 85-90. [CrossRef] [PubMed]

27. Taihao, Q. Molecular Mechanisms of Skin Aging and Age-Related Diseases; Quan, T., Ed.; CRC Press: New York, NY, USA, 2016.

28. Decorps, J.; Saumet, J.L.; Sommer, P.; Sigaudo-Roussel, D.; Fromy, B. Effect of ageing on tactile transduction processes. Ageing Res. Rev. 2014, 13, 90-99. [CrossRef] [PubMed]

29. Matsui, Y.; Sugiyama, K.; Kamei, M.; Takahashi, T.; Suzuki, T.; Katagata, Y.; Ito, T. Extract of passion fruit (Passiflora edulis) seed containing high amounts of piceatannol inhibits melanogenesis and promotes collagen synthesis. J. Agric. Food Chem. 2010, 58, 11112-11118. [CrossRef] [PubMed]

30. Mukherjee, P.K.; Maity, N.; Nema, N.K.; Sarkar, B.K. Bioactive compounds from natural resources against skin aging. Eur. J. Integr. Med. 2011, 19, 64-73. [CrossRef] [PubMed]

31. Papakonstantinou, E.; Roth, M.; Karakiulakis, G. Hyaluronic acid: A key molecule in skin aging. Dermatoendocrinology 2012, 4, 253-258. [CrossRef] [PubMed]

32. Prosdocimi, M.; Bevilacqua, C. Exogenous hyaluronic acid and wound healing: An updated vision. Panminerva Med. 2012, 54, 129-135. [PubMed]

33. Maquart, F.X.; Bellon, G.; Gillery, P.; Wegrowski, Y.; Borel, J.P. Stimulation of collagen synthesis in fibroblast cultures by a triterpene extracted from Centella asiatica. Connect. Tissue Res. 1990, 24, 107-120. [CrossRef] [PubMed]

34. Coldren, C.D.; Hashim, P.; Ali, J.M.; Oh, S.-K.; Sinskey, A.J.; Rha, C. Gene expression changes in the human fibroblast induced by Centella asiatica triterpenoids. Planta Med. 2003, 69, 725-732. [PubMed]

35. Abdullah, N.H.; Thomas, N.F.; Sivasothy, Y.; Lee, V.S.; Liew, S.Y.; Noorbatcha, I.A.; Awang, K. Hyaluronidase inhibitory activity of pentacylic triterpenoids from Prismatomeris tetrandra (Roxb.) K. Schum: Isolation, synthesis and QSAR study. Int. J. Mol. Sci. 2016, 17, 143. [CrossRef] [PubMed]

36. Wang, K.H.; Lin, R.D.; Hsu, F.L.; Huang, Y.H.; Chang, H.C.; Huang, C.Y.; Lee, M.H. Cosmetic applications of selected traditional Chinese herbal medicines. J. Ethnopharmacol. 2006, 106, 353-359. [CrossRef] [PubMed]

37. Tanaka, A.; Zhu, Q.; Tan, H.; Horiba, H.; Ohnuki, K.; Mori, Y.; Yamauchi, R.; Ishikawa, H.; Iwamoto, A.; Kawahara, H.; et al. Biological activities and phytochemical profiles of extracts from different parts of bamboo (Phyllostachys pubescens). Molecules 2014, 19, 8238-8260. [CrossRef] [PubMed]

38. Zhu, Q.; Nakagawa, T.; Kishikawa, A.; Ohnuki, K.; Shimizu, K. In vitro bioactivities and phytochemical profile of various parts of the strawberry (Fragaria $\times$ ananassa var. Amaou). J. Funct. Foods 2015, 13, 38-49. [CrossRef]

39. Yun, S.-S.; Kang, M.-Y.; Park, J.-C.; Nam, S.-H. Comparison of anti-allergenic activities of various polyphenols in cell assays. J. Appl. Biol. Chem. 2010, 53, 139-146. [CrossRef]

40. Mira, A.; Tanaka, A.; Tateyama, Y.; Kondo, R.; Shimizu, K. Comparative biological study of roots, stems, leaves, and seeds of Angelica shikokiana Makino. J. Ethnopharmacol. 2013, 148, 980-987. [CrossRef] [PubMed]

41. Kishikawa, A.; Ashour, A.; Zhu, Q.; Yasuda, M.; Ishikawa, H.; Shimizu, K. Multiple biological effects of olive oil by-products such as leaves, stems, flowers, olive milled waste, fruit pulp, and seeds of the olive plant on skin. Phytother. Res. 2015, 29, 877-886. [CrossRef] [PubMed]

(C) 2017 by the authors. Licensee MDPI, Basel, Switzerland. This article is an open access article distributed under the terms and conditions of the Creative Commons Attribution (CC BY) license (http:/ / creativecommons.org/licenses/by/4.0/). 